\title{
Review
}

\section{Militant acts: The role of investigations in radical political struggles}

\author{
Marcelo Hoffman, \\ SUNY Press, 2019, iii+192 pp., ISBN: 978-1438472621
}

Contemporary Political Theory (2021) 20, S164-S167. https://doi.org/10.1057/s41296020-00437-x; published online 25 August 2020

Marcelo Hoffman's Militant Acts: The Role of Investigations in Radical Political Struggles reconstructs the genealogy of the militant investigation. At the center of this genealogy is the practice of workers' inquiry in the Marxist tradition. Although socialist study of workers' lives and working conditions predates Marx, his 1880 questionnaire eventually became a central point of reference (p. 28). Workers' inquiry, however, has played a rather marginal role in orthodox Marxism. Lenin seems to have abandoned the workers' inquiry after practicing it briefly (pp. 38-42). Mao, by contrast, gave the practice a rich and independent elaboration (pp. 45-48). Marx's and Mao's approaches lived on in dissident Trotskyist and exTrotskyist practices of the 1950s and 1960s (pp. 52-67), in Italian workerism (pp. 68-80), and in the variety of French Maoisms that flourished after 1968 (pp. 81-100). After the 1970s, the practice went into decline, but new forms of militant investigation may be reappearing today (pp. 133-142).

Hoffman's book draws on an impressive range of sources in at least five languages. It takes a longer historical view than many previous studies of the topic. Militant Acts will be particularly valuable for those who engage with French leftist thinkers of the 1970s. Anyone interested in the history of the Prisons Information Group (GIP), with which Foucault was associated, will acquire a broader historical perspective from this book, as will those seeking a better understanding of the militant practices of Badiou and his group, the Union of Marxist-Leninist Communists of France (UCFML).

In the first chapter, Hoffman discusses the notion of militant investigation, the broader category under which he classes the workers' inquiry. Militant investigations should be seen as one way of addressing the problem of 'the constitution of knowledge in radical political struggles and theories' (p. 2). Methods vary, but may include questionnaires, interviews, collective meetings with informants, and the creation of platforms for longer-form narrative writing from workers and other subalterns. Despite these variety of methods and uses, two central concerns normally drive militant investigations: combatting the distortions or silences found

(c) 2020 Springer Nature Limited. 1470-8914 Contemporary Political Theory Vol. 20, S4, S164-S167 
in official commissions of inquiry and encouraging the self-activity of the oppressed (pp. 2, 5-6). Militant investigations should be distinguished from commissions of inquiry organized by state actors, as well as from scholarly investigations undertaken by academics (pp. 6, 7). Although paradigmatically associated with workers' inquiries, militant investigations have also been undertaken on the basis of radical struggles concerning peasants, prisoners, patients, women, racialized groups, and students, among others (p. 1).

For Hoffman, the main theoretical problem is how to assess the success or failure of militant investigations. Prior treatments of the question, he contends, have focused too much on dismal response rates, while neglecting the subtler effects of investigations (pp. 13-16). In particular, militant investigations have the 'potential to instantiate forms of collective political subjectivity' even when response rates from target groups are low (p. 16). Militant investigations reframe the self-conceptions of both the investigator and the investigated. They erode traditional hierarchies of knowledge and represent a tool for non-vanguardist approaches to Marxism (pp. 16-20).

In the second chapter, Hoffman turns to an overview of the investigation as practiced and conceived by Marx, Lenin, and Mao. In 1880, Marx published a list of more than one hundred questions, along with some prefatory remarks, in the French paper La Revue socialiste. The history of this questionnaire and its aftermath is well known, but Hoffman treats it ably and corrects certain misconceptions (pp. 28-36). After a discussion of Lenin's brief dalliance with workers' inquiry, Hoffman turns to Mao, whose experience in Hunan in 1927 led him to rethink the revolutionary potential of the peasantry. Mao prefers collective fact-finding missions and group interviews on the ground to Marx's questionnaire. In so doing, Mao turns the investigation into a device for transforming the subjectivity of the revolutionary intellectual as much as that of the investigated group (pp. 47, 48).

Chapter three charts the genealogy of a different type of investigation, the narrative account of workers' experience, as it was developed within the JohnsonForest Tendency of Trotskyism (the project of C.L.R. James and Raya Dunayevskaya) before making its way into France via the Socialisme ou Barbarie group (associated with Cornelius Castoriadis and Claude Lefort) and thence into Italian workerism. This history has recently been reviewed in great detail by Asad Haider and Salar Mohandesi (Haider and Mohandesi 2013). Hoffman follows them in emphasizing the importance of The American Worker (1947), which combines an experiential narrative written by factory worker Phil Singer with a theoretical appendix penned pseudonymously by the Johnson-Forest Tendency's Grace Lee Boggs. Although the narrative form departs from the questionnaire method of Marx's inquiry, Hoffman also follows Haider and Mohandesi in treating it as a genealogical successor (pp. 56, 57). The American Worker provided an important model for dissident Marxisms in both France and Italy (pp. 66, 69).

(c) 2020 Springer Nature Limited. 1470-8914 Contemporary Political Theory Vol. 20, S4, S164-S167 S165 
In chapter four, Hoffman traces the afterlife of Mao's approach to investigation in the various French Maoist groupuscules of the 1970s. Special emphasis is placed on Le livre des paysans pauvres (1975), the result of five years of countryside investigation undertaken by the UCFML. Hoffman also discusses the differing conceptions of the investigation in other Maoist groups of the time, such as the more famous Gauche Prolétarienne (GP). He underlines the connection between the investigation and debates about political organization, party structure, and the practice of établissement, i.e., of sending militants to take up jobs in factories and farms alongside those they were trying to organize (pp. 82-89). The fifth chapter then turns to Foucault, examining his own militant activity within the GIP in the early 1970s, as well as his parallel attempt to do the genealogy of official state-sponsored investigations (pp. 106-110). Hoffman finds that the GIP's famous prisoners' inquiry has genealogical ties to each of the earlier lineages of investigation (pp. 123-126). Finally, Hoffman's conclusion examines the 'rebirth' of the militant investigation today in a number of sites, from the Argentine militant research group Colectivo Situaciones to new workers' inquiries into affective labor (pp. 133-142).

This is a slim volume, clocking in at 142 pages excluding reference material. At times, the book feels too brief. A more thorough treatment of some of the theoretical debates connected to the workers' inquiry might have been expected. Both the orthodox and dissident Marxist disputes about the role of the intellectual could stand to be highlighted more, and no mention is made of Foucault's conceptualization of the 'specific intellectual'. One might also have expected a mention of the peculiar afterlife in China itself of Mao's 1927 investigation, where it played an important role during not only the Cultural Revolution (which Hoffman alludes to in passing), but also the earlier Great Leap Forward (cf. Ghosh 2020, pp. 47-53, 265-278).

The concept of workers' inquiry is the guiding frame in much of the literature with which Hoffman engages. In framing the book instead around the concept of militant investigation, Hoffman thus substantially enlarges its purported scope. Yet Militant Acts does not spend much time on other lineages of militant investigation outside of (dissident Trotskyist) Marxism and Maoism. The pre-Marxist socialist tradition is mentioned but not treated at much length (pp. 123-126). It would be helpful to know whether this tradition amounts to a genuine alternative. Although the conclusion provides suggestive hints, in general other types of radical movements are brought up only in passing. There is also no discussion of the rich theorization of the relationship between social inquiry, democracy, and the formation of publics in the pragmatist tradition. One consequence of that absence is that, although Hoffman stresses the subtler effects of investigation on collective subjectivity, he does not consider the mediation of this subjectivity-formation through the constitution of alternative publics sustained by ongoing militant inquiries (cf. Mathiesen 2006, pp. 193-197). 
Along related lines, Hoffman's book encounters a noticeable demarcation problem about militant investigations. What differentiates them from other investigations? Three answers suggest themselves: the identity of the inquirers, the nature of their methods, and their specific objectives. Complications arise for each. First, Hoffman himself notes the importance of 'hybrid' forms of investigation; after all, militants may also be scholars or even government officials (pp. 66, 67; p. 9). Again, Hoffman acknowledges that some forms of academic research use participatory methods that seek to disrupt hierarchies of knower and known (pp. 70, 71). Finally, inquiries of every type are usually overdetermined in their objectives. A state-sponsored investigation may delegate responsibilities to a foundation or a scholar, who in turn may involve radical actors or incorporate a radical agenda. It is not hard to think of difficult limit cases. How, for example, would Hoffman classify W.E.B. Du Bois's many sociological investigations of African Americans?

In sum, Militant Acts makes a significant contribution to our understanding of the pre-history of the GIP and UCFML's investigative practices and makes important strides in connecting French leftist practices of the 1970s with earlier practice and theory in the United States, France, and Italy. It is best seen not as a comprehensive account of the role of militant investigations in radical political struggles, but rather as an extended historical case study of several interweaving traditions of militant research. In this regard, it has much to offer to anyone interested in a radical politics of knowledge today.

\section{References}

Ghosh, A. (2020). Making It Count: Statistics and Statecraft in the Early People's Republic of China. Princeton: Princeton University Press.

Haider, A. and S. Mohandesi. 2013. Workers' Inquiry: A Genealogy. Viewpoint Magazine 3. https:// www.viewpointmag.com/2013/09/27/workers-inquiry-a-genealogy/. Accessed 27 Mar 2013.

Mathiesen, T. (2006). Prison on Trial. Winchester, UK: Waterside Press.

Publisher's Note Springer Nature remains neutral with regard to jurisdictional claims in published maps and institutional affiliations.

Alex J. Feldman

University of West Georgia, Carrollton, GA 30118, USA afeldman@westga.edu

(c) 2020 Springer Nature Limited. 1470-8914 Contemporary Political Theory Vol. 20, S4, S164-S167 S167 